\title{
IMPACT CASH FLOW RIGHT LEVERAGE OF CONTROLLING SHAREHOLDER ON PERFORMANCE IN INDONESIA
}

\author{
I Putu Sugiartha Sanjaya \\ Fakultas Ekonomi Universitas Atma Jaya Yogyakarta, Indonesia \\ Email:putu1970@mail.uajy.ac.id
}

\begin{abstract}
The purpose of this study is to investigate the impact of cash flow rights leverage of controlling shareholder on performance. The ownership of common stock has some rights such as control rights and cash flow rights. Control rights are the rights of common shareholders to elect board of directors and other company's policies, such as the issuence of securities, stock split and substansial changes in company's operation (Du and Dai, 2005). Cash flow rights are the financial claims of shareholders on the companies (La Porta et al., 1999). Case in Indonesia, commonly there are differences between control rights and cash flow rights. It is called cash flow right leverage. The large leverage indicates the large agency conflict between controlling shareholder and non-controlling shareholders. The low leverage indicates the low agency conflict. It will impact on performance. If the control rights are greater than cash flow rights, it indicates the larger agency problem. It indicates that the power of the controlling shareholder in the company is larger than claim to the firm. It is incentive for a controlling shareholder to expropriate non-controlling shareholders through utilizing assets of company for his/her private benefit. This study uses the sample of the manufacturing companies listed in the Indonesian Stock Exchange during the period 2001-2007. Performance is measured by Return on Assets (ROA). The results of this study show that the cash flow right leverage of controlling shareholder has negative impacts on performance. It means the large agency conflict (cash flow right leverage) between controlling and non-controlling shareholders reduce performance. The results of this study can give contribution for Indonesia Financial Service Authority (Otoritas Jasa Keuangan (OJK)) to monitor public companies in Indonesia. This institution more focus for companies which has large cash flow right leverage. Because, it indicates the large agency problem between controlling and non-controlling shareholders.
\end{abstract}

Keywords: controlling shareholder, control rights, cash flow rights, cash flow right leverage, agency conflict, and performance.

Abstrak: Tujuan studi ini adalah untuk menginvestigasi dampak dari cash flow right
leverage pemegang saham pengendali pada kinerja. Pemagang saham biasa mempunyai
beberapa hak seperti hak kontrol dan hak aliran kas. Hak kontrol adalah hak dari
pemegang saham biasa untuk memilih dewan direktur dan kebijakan-kebijakan
perusahaan seperti penerbitan saham, pemecahan saham, dan perubahan-perubahan
operasi perusahaan (Du dan Dai, 2005). Hal aliran kas adalah klaim keuangan dari para
pemegang saham terhadap perusahaan (La Porta et al., 1999). Kasus di Indonesia,
secara umum ada perbedaan antara hak control dan hak aliran kas. Ini sering disebut
sebagai cash flow right leverage. Besaran leverage ini mengindikasikan besaran konflik
keagenan antara pemegang saham pengendali dan pemegang saham bukan pengendali.
Semakin kecil leverage ini, hal ini menunjukkan konflik keagenan juga semakin 
menurun. Leverage ini akan berdampak pada kinerja. Jika hak kontrol lebih besar disbanding hak aliran kas, ini mengindikasikan masalah keagenan yang besar. Ini menunjukkan bahwa kekuatan atau kendali dari pemegang saham pengendali dalam perusahaan lebih besar dibanding klaimnya kepada perusahaan. Ini dapat menjadi peluang bagi pemegang saham pengendali untuk mengekspropriasi pemegang saham bukan pengendali melalui pemanfaatan aset perusahaan untuk manfaat privat pemagang saham pengendali. Studi ini menggunakan sampel perusahaan-perusahaan manufaktur yang terdaftar di Bursa Efek Jakarta selama periode 2001-2007. Kinerja diukur dengan Return on Assets (ROA). Hasil studi ini menunjukkan bahwa cash flow rigtht leverage dari pemegang saham pengendali berdampak negatif pada kinerja. Hasil ini menegaskan bahwa konflik keagenan yang besar (cash flow right leverage) antara pemegang saham pengendali dan pemegang saham bukan pengendali menurunkan kinerja. Hasil studi ini dapat memberi kontribusi kepada Otoritas Jasa Keuangan (OJK) untuk mengawasi perusahaan-perusahaan publik di Indonesia. Lembaga ini dapat lebih memfokuskan pada perusahaan-perusahaan yang mempunyai cash flow right leverage yang besar. Karena ini mengindikasikan masalah keagenan yang besar antara pemegang saham pengendali dan pemegang saham bukan pengendali.

Kata Kunci: pemegang saham pengendali, hak control, hak aliran kas, cash flow right leverage, konflik keagegan, dan kinerja.

\section{INTRODUCTION}

The objective of this study is to investigate whether the cash flow right leverage of controlling shareholder negatively influence on performance. According to Claessens et al. (2000), most public companies in Indonesia are owned by single controlling stockholder. Controlling shareholder is also the largest control rights of ultimate ownership. Febrianto (2005) found that $92 \%$ public companies were owned ultimately. The finding is consistence with Siregar (2008). Siregar (2008) documented 99, 09\% public companies in Indonesia owned ultimately at $10 \%$ cut of point of control rights. The concentration will generate the separation between cash flow rights and control rights.

It will reflect entrenchment or alighnment effect. Morck et al. (1988) was the first study about entrenchment and alignment. Entrenchment is a situation which control rights entrench controlling shareholder to expropriate (abuse of power) non-controlling shareholders. Based on Putusan Mahkamah Agung No. 615 K/Pid.Sus/2010 (Mahkamah Agung, 2010), it shows an anecdote evidence about PT Bank Century Tbk (BC) giving loan (credit) to PT Wibowo Wadah Rejeki (WWR) and PT Accent Investindo Indonesia (AII). It shows expropration by controlling shareholder in public company.

Based on Putusan Mahkamah Agung No. 615, Robert Tantular has some role to this case. Based on list of ownership of BC in financial statements, there is no such name as Robert Tantular. Based on the information on detikNews (2008) introducing that the shareholders of BC on September 30, 2008 is Clearstream Banking S.A. Luxembourg 11.5\%, First Gulf Asia Holding Limited (d/h Chinkara Capital Limited) 9.55\%, PT Century Mega Investindo 9\%, PT Antaboga Delta Sekuritas 7.44\%, PT Century Super Investindo $5.64 \%$, and others less than $5 \%$ is $57,21 \%$. Robert's name can be found as BC's shareholder by tracing the ultimate ownership. The ultimate ownership of BC is Robert Tantular, Hesham Alwarraq, and Rafat Ali Rizfi. Robert owned BC through PT 
Century Mega Investindo 9\%, PT Century Super Investindo 5.64\%, and PT Antaboga Delta Sekuritas 7.44\%. PT Aditya Rekautama had 82.18\% Antaboga's stock and remainder Antaboga's stock $17.82 \%$ is owned by PT Mitrasejati Makmurabadi. The $12.5 \%$ of PT Aditya Rekautama's stock is ownerd by Robert, Hartawan Aluwi, and Budi PV Tanudjaja. Robert and Hartawan are the sons in law of Sukanta Tanudjaja. Sukanta Tanjudjaja was owner of Great River. Budi is family of Sukanta (VIVAnews-Bisnis, 2009).

According to Siregar (2008), pyramid mechanism is popularly used by controlling shareholder as 66\% (865 from 1.302 observations). There are some controlling shareholder on public firms in Indonesia such as family, government, and dispersed ownership by financial institution, companies with dispersed ownership, and the other controlling shareholder. Family is most dominant as 56\% (724 from 1.302 observations). The position of controlling shareholder can be known on chain 10 and 11 chain of ownerships. It indicates the complexity of the ownership in public firms and also controlling shareholder is very hard to be identified.

The complexity of the ownership will raise entrenchment effect of controlling shareholder. According to Fan and Wong (2002), when the controlling shareholder is entrenched by his/her control rights and there is large separation of control rights and cash flow rights, reliability of the accounting information is reduced. It occurs because the controlling shareholder controls effectively to firm and he/she also controls the process of financial reporting. Therefore, this condition is an incentive for controlling shareholder to expropriate firm's asset to increase his/her private benefit.

Sanjaya (2011) also documents that family is the greatest controlling shareholder in Indonesia at $68.49 \%$. Siregar (2008) also documents that $33.56 \%$ of controllong shareholders are also the member of board of director. It suggests that directors of public companies are the controlling shareholder or the family member of a controlling shareholder. Involvement in the board of directors is another way to improve the control of ultimate ownership.

In the next section, theoritical review and hypothesis development will be presented. This will be followed with research design. It concludes by presenting the result conclusion.

\section{LITERATURE REVIEW}

Agency Theory. In the dispersed context, conflict of interest exists between manager and shareholders. This is due to the fact that manager has most power to control the company. Therefore, manager does not always act in the best interests of the shareholder because manager has also interest for his/her personal benefit. Thus, there is an incentive to encourage manager to exploit the company's assets for his/her personal benefit, which may become a problem for shareholders.

According to Villalonga and Amit (2006), this problem is called Agency Problem I or according to Bozec and Laurin (2008), it is Type I Agency Costs. To mitigate the problem, the shareholders make a group of shareholders and become large shareholders to monitor manager so that manager will operate the company in accordance to the best interest of shareholders. Next, controlling shareholders ask manager to make decisions only for their benefit as special dividend. It can be harmful for non-controlling shareholders. This is called an agency problem between controlling and non-controlling 
shareholders or Agency Problem II (Villalonga and Amit, 2006) or Type II Agency Costs (Bozec and Laurin, 2008). For concentrated ownership, the company is controlled by the controlling shareholder. In reality, corporate manager is a family of controlling shareholder. In this situation, the agency problem switches from shareholder and manager to controlling shareholder and non-controlling shareholders.

Empirical study by La Porta et al. (1999) was monumental study in the context of concentrated ownership. La Porta et al. (1999) evaluate the potential agency problem between controlling shareholder and non-controlling shareholders when there are subtancial defferences between voting and cash flow rights. Claessens and Fan (2002) suggeste that agency conflicts occur because there is a large divergence between voting and cash flow rights. If the value of cash flow rights is the same as the value of control rights, it indicates no agency problem between controlling shareholder and non-controlling shareholders.

The increasing of voting rights leads the controlling shareholder to expropriate the company's assets for his/her private benefits. With the more control, a controlling shareholder can exploit the company's assets. It will impact the decreasing of firm performance. According to Shleifer and Vishny (1997: 759), "as ownership gets beyond a certain point, the large owners gain nearly full control and prefer to use firms to generate private benefits of control. That are not shared by minority shareholders". This statement is the same as the argument of the negative entrenchment effect. The argument suggests that the controlling shareholder is motivated to fulfil her/his private benefit (Yeh, 2005).

Corporate Governance. According Cadbury Committee (1992), corporate governance is the system by which companies are directed and controlled. Boards of directors are responsible for the governance of their companies. The shareholders' role in governance is to appoint the directors and the auditors and to satisfy themselves that an appropriate governance structure is in place. The responsibilities of the board include setting the company's strategic aims, providing the leadership to put them into effect, supervising the management of the business and reporting to shareholders on their stewardship. The board's actions are subject to laws, regulations and the shareholders in general meeting.

Controlling shareholder and Performance. Claessens et al. (1999) empirically investigate the influence of ownership structure of companies in East Asian on firm performance. The study used 2,658 companies including Indonesia on 1996. They document that the increasing of control rights of controlling shareholder has negative impact on firm performance. They also test the impact of large divergence between control and cash flow rights on firm performance. They find that there is negative impact of divergence on firm performance.

Claessens et al. (2002) investigate the effect of control rights of controlling shareholder on the value of the public firm in East Asian. They used 1,301 firms from eight countries in East Asian. They found that the large of control rights has negative impact on the value of the firm. Lins (2003) investigates the influence of managerial ownership and non-manager block holders on the value of the firm in 18 countries. Lins (2003) finds that the large control of manager has negative influence on the value of the firm. 
Lemmon and Lins (2003) investigate the impact of public ownerships on the firm performance during the financial crisis in East Asian on July 1997. They collected data from Woldscope for 800 companies in East Asian. Cash flow right leverage is to measure the divergence between voting rights and cash flow rights. The results of their study were the divergence of cash flow and control rights has negative impact on firm performance.

Yang et al. (2012) examine whether efficiency monitoring has a positive influence on corporate performance with panel data of listed firms in Taiwan from 2005 to 2010. Yang et al. (2012) use holding the percentage of shares by controlling shareholder. The percentage of shares is held directly and indirectly by the ultimate ownership. The ultimate is the largest shareholder, the chairperson, or general manager and his/her family, or the management team that has the largest influence on operating company. The results show the relation between the board-seat control-cash rights divergence and corporate performance often reflecting in inverted curve. Corporate performance has the tendency to become an inverted curve when the board seat control-voting right divergence exceeds the 63.5 percent threshold. When the said power exceeds a certain level of board-seat controlvoting rights divergence, large shareholder may harm the interests of non-controlling shareholders and reduce corporate performance. Board seat control is percentage of director and supervisor seats under the control of the ultimate owner. Shareholding control is percentage of shares held directly and indirectly by the ultimate owner.

Baek et al. (2004) investigate the effect of corporate governance on firm performance during a crisis in Korean companies. Baek et al. (2004) use set of measures for corporate governance before the financial crisis to explain changes in firm performance. Controlling shareholder has voting rights exceed his/her cash flow rights. It can create severe agency problems between controlling shareholder and non-controlling shareholders. For crisis period, Baek et al. (2004) investigate whether divergence between cash flow rights and voting rights are associated with lower market value. Baek et al. (2004) find that the crisis in Korea has a significant and negative effect on the market value of firms. Firms with concentrated ownership by owner-managers and concentrated ownership by affiliated firms experience larger drop in firm performance. Firms in which the voting rights exceed cash flow rights have significantly lower firm performance. These results support the findings of Mitton (2002) that corporate governance has a significant influence on firm performance in a crisis. It also suggests that the negative impact is greater on firms in which controlling shareholder has stronger incentives to expropriate the resources of the firm.

Joh (2003) examine whether ownership structure has influence on firm performance before the crisis. Joh (2003) examine whether shareholder with more control rights than ownership rights expropriate firm's assets before the crisis. A controlling shareholder has an incentive to expropriate firm's assets as his/her private benefits when voting rights exceed cash flow rights of controlling shareholder. The expropriation is most likely when the divergence between voting and cash flow rights are large. Firms experiencing greater expropriation show the lower performance. Joh (2003) also examine whether business groups have lower firm performance than independent firms. Joh (2003) used 5,829 Korean firms during the pre-crisis period of 1993-1997. Joh (2003) measures firm performance through its profitability. The results show that firm performance is lower when cash flow rights of controlling shareholder are lower. Firm performance is low for firms when the divergence between voting rights and cash flow rights is high. 
Barontini and Caprio (2004) examined the relation between the firm performance and the size of voting and cash-flow rights of the largest shareholder for Continental European corporations. Barontini and Caprio (2004) test some hypotheses concerning the link between firm performance and ownership in Continental Europe such as firm performance grow with the share of the cash-flow rights held by the largest shareholders and firm performance decrease as the dissociation between cash-flow and voting rights ownership grows. The results show firm performance decrease as the dissociation between cash-flow and voting rights ownership grows. Both Tobin's Q and ROA decrease as the wedge between cash flow and voting rights held by the largest shareholder grows. The evidence is less clear as far as the relation between performance and cash flow rights is concerned.

Mitton (2002) examines other aspects of corporate governance that vary at the firm level. Mitton (2002) examines disclosure quality, ownership structure, and corporate diversification which have a significant impact on the performance of firms during the crisis. Mitton (2002) uses firm-level data from the five East Asian crisis economies of Indonesia, Korea, Malaysia, the Philippines, and Thailand to study the impact of corporate governance on firm performance during the crisis. Corporate governance is the means by which minority shareholders are protected from expropriation by managers or controlling shareholder. Corporate governance is more critical in a financial crisis for two reasons. First, expropriation of minority shareholders could become more severe during a crisis. Second, a crisis could force investors to recognize and take account of weaknesses in corporate governance that existed all along. Mitton (2002) finds that corporate governance has a significant effect on firm performance during the East Asian crisis. Mitton (2002) differentiates between cash flow rights and voting rights of the largest shareholder. Cash flow/voting rights divergence increases the incentive for expropriation.

Bozec and Laurin (2008) investigate the separation of voting and cash flow rights on various performances when the large shareholder has the opportunity to expropriate as high free cash flows in the firm and the incentive to expropriate as low cash flow rights. They use a sample of more than 400 of the largest public Canadian closely-held firms from 1995 to 1999 . They find the separation between voting and cash-flow rights has negative effect on firm performance when the large divergence. It indicates that the dominant shareholder gains effective control of the firm has negative impact to the company.

The Research Hypothesis. Claessens et al. (1999) find that the divergence has negative affect to value of the company. Lemmon and Lins (2003) find negative impact of divergence on value of firm. Baek et al. (2004) find that the crisis in Korea has negative effect on the market value of firms. Bozec and Laurin (2008) find the separation between voting and cash-flow rights has negative effect on firm performance when the large divergence. Yang et al. (2012) documents inverted curve on the relation of divergence between the board-seat controls-voting right and corporate performance.

There are some negative impacts the increasing cash flow right leverage. In the context of concentrated ownership, agency problem can be peroxided by the leverage. If the leverage is greater, it indicates a large agency problem. Controlling shareholder has more power to control the company than the claim to controlling shareholder to company. It means power is larger than claim. This condition encourages controlling shareholder to expropriate the company's assets for his/her personal benefit. This is entrenchment effect 
of controlling shareholder. When the low leverage, it indicates low agency problems because cash flow rights is close to or same as the voting rights. In this condition, a controlling shareholder does not expropriate the company's asset because the controlling shareholder will not reduce his/her claims for the company. This is the alignment effect of the controlling shareholder.

Based on the conditions, this study expects that the large cash flow right leverage leads the controlling shareholder to expropriate the non-controlling shareholders. It will reduce the performance. The low leverage indicates less opportunity for controlling shareholder to expropriate the non-controlling shareholders. It will positive impact on the performance. The study expects that the leverage will have negative impact to the performance. To test this expection empirically, this paper formulates hypothesis as follow.

$\mathbf{H}_{\mathrm{a}}$ : cash flow right leverage of controlling shareholder has a negative impact on performance.

\section{RESEARCH METHOD}

Sample. Sample of this study is manufacturing companies listed on the Indonesian Stock Exchange from 2001 to 2007. Sampling was done by purposive sampling because the author wants specific information from the target as manufacturing industries listed since 2001 and publishes the annual financial statements from 2001 to 2007. Data collection techniques of this study are the data archive. One form of collection of archived data is secondary data. Secondary data obtained from several sources as Indonesian Stock Exchange for the audited financial statements, OSIRIS database for ultimate ownership, and the Indonesian Business Data Centre for ultimate ownership.

Variable and Measurement. Independent variable of this study is cash flow right leverage of controlling shareholder. This variable is measured by cash flow right leverage. La Porta et al. (1999) suggest cash flow rights are financial claims against to the company. Cash flow rights are direct and indirect cash flow rights. Direct cash flow rights is the percentage of shares which is held by shareholder in public companies behalf of himself. Indirect cash flow rights is the number of multiplications shareholders ownership percentage in each chain of ownership. Cash flow rights is sum of direct and indirect cash flow rights.

According to La Porta et al. (1999), control is the voting rights to participate in setting corporate policy. Voting rights include the direct voting rights and the indirect voting rights. The direct voting rights are the percentage of shares which is held by controlling shareholder on behalf of himself at a company. The direct voting rights is equal direct cash flow rights. Indirect voting rights is the sum of the minimum control in any chain of ownership (La Porta et al., 1999). Control rights is the sum of the relationship between the direct control rights and indirect control rights.

Cash flow rights leverage is control rights minus cash flow rights. The larger leverage between cash flow rights and voting rights suggests the higher the increasing control rights exceed cash flow rights. Dependent variable is firm performance. The performance is measured by return on assets. Accordance to Dechow et al. (1998) and Dechow (1994), earnings are information about future cash flow. It is more relevant information for investors. Demsetz and Villalonga (2002) suggest that accounting 
earnings is better to reflect the effect of concentrated ownership than market value. Accounting earnings measures what have and have not been done by manager. Joh (2003) also suggests that accounting profitability is likely a better performance measure than stock market-based measures. Therefore, this study uses return on assets reflecting the firm performance. Return on Asset (ROA) is earnings divided assets. This study uses operating earnings. Assets is total assets both current and non-current assets.

\section{RESULTS}

\section{Data Description}

Table 1. Descriptive Statistics

\begin{tabular}{lcccccc}
\hline & $\mathrm{N}$ & Minimum & Maximum & Mean & Std. Dev. & Variance \\
\hline ROA & 604 & -.08 & .24 & .057 & .05665 & .003 \\
LEVERAGE & 604 & -.66 & 13.07 & 1.402 & 1.775 & 3.149 \\
ASSETS & 604 & 24.22 & 31.78 & 27.296 & 1.510 & 2.279 \\
CFRL & 604 & .00 & .43 & .036 & .077 & .006
\end{tabular}

Valid N (list wise)

Based on Table 1, the average value of return on assets (ROA) is 0.057. The minimum value of return on assets is -0.08 . The value means that there are companies on the sample of this study which are negative performance or negative earnings. It means the performance of companies on the period (2001-2007) have bad performance. But, the maximum of return on assets is 0.24 . It means some companies have good performance. On the mean value, performance is still positive and it is good performance.

The mean value of cash flow right leverage (CFRL) is 0.036 or $3.6 \%$. This condition depicts higher voting rights than cash flow rights. It means controlling shareholder has more power than financial claim. It is incentive for controlling shareholder to expropriate non-controlling shareholders. It will have a negative impact on company. The maximum value of cash flow right leverage is 0.43 and minimum is 0 .

Hypothesis Testing. This study uses some empirical model to test hypothesis. This study uses single regression in model 1. Dependent variable is ROA and CFRL is independent variable. In model 2, 3, and 4, this study uses multiple regressions. In model 2, this study tests hypothesis with variable assets as controlling variable. In model 3, this study replaces assets with leverage as controlling variable. The last model, this study put leverage and assets in the empirical model. The results of the test are as follow on Table 2.

This table reports regression results of the divergent between voting rights and cash flow rights on firm performance. In this table, CFRL is independent variable for the divergence between voting rights and cash flow rights. Performance is measured by return on assets. Return is operating income in accounting earnings. The earnings are on income statement. Leverage and Asset are controlling variable. Leverage is liabilities divided in equity. Assets are log total asset. T-statistics are in parentheses. ***and ** denote significance at the $1 \%$ and $5 \%$ levels, respectively. 
Table 2. Test Result Of Hypothesis

\begin{tabular}{lllll}
\hline $\begin{array}{l}\text { Independent } \\
\text { variable }\end{array}$ & Model 1 & Model 2 & Model 3 & Model 4 \\
\hline Intercept & 0.059 & 0.036 & 0.046 & -0.089 \\
& $(23.210)^{* * *}$ & $(0.851)$ & $(15.404)^{* * *}$ & $(-2.123)^{* *}$ \\
CFRL & -0.061 & -0.061 & -0.067 & -0.068 \\
& $(-2.037)^{* *}$ & $(-2.039)^{* *}$ & $(-2.355)^{* *}$ & $\begin{array}{l}(-2.420)^{* *} \\
\text { LEVERAGE }\end{array}$ \\
& & & 0.009 & 0.011 \\
ASSETS & & 0.001 & $(7.784)^{* * *}$ & $(8.456)^{* * *}$ \\
& & $(0.561)$ & & 0.005 \\
& & & & $(3.213)^{* * *}$ \\
$\begin{array}{l}\text { R-squared } \\
\begin{array}{l}\text { Number } \\
\text { observations }\end{array}\end{array}$ & 0.006 & 0.007 & 0.097 & 0.010 \\
\hline
\end{tabular}

The results in Table 2 indicate that CFRL which is divergence between control rights and cash flow rights. CFRL in Table 2 has negative and significant impact on firm performance. The impact of CFRL on firm performance is still consistent in model 2, 3, and 4 . The results indicate that the large of divergence between control rights and cash flow rights has negative impact on firm performance. Increasing of leverage will lead decreasing of firm performance. The larger leverage leads the lower firm performance.

The results of this study are strongly support for arguments of agency conflict in concentrated ownership. The large or low cash flow right leverage or divergence indicates large or low agency problem in company. The large leverage indicates large agency problem in company. The large agency conflict will impact to the company. Generally, a controlling shareholder will put the resources of company for his/her interest not for company or non-controlling shareholder.

Based on the result in Table 2, alternate hypothesis is supported. This results are consistent with the previous study such as Claessens et al. (1999), Lemmon and Lins (2003), Baek et al. (2004), Bozec and Laurin (2008), and Yang et al. (2012). They find that cash flow right leverage has negative impact on firm performance.

The leverage will entrench controlling shareholder to expropriate non-controlling shareholders. A case in Bank of Century Tbk is an expropriation by controlling shareholder in Indonesia. Expropriation is occurred because a controlling shareholder has lower financial incentives compared with his/her control to the company. This situation indicates the agency conflict between controlling shareholder and non-controlling shareholders. The controlling shareholder can make decisions exclusively for her/his benefit. The larger cash flow right leverage is an incentive and opportunities for controlling shareholder to expropriate non- controlling shareholders (Gugler and Yurtoglu, 2003).

The results of this study also support the argument of negative entrenchment effect (Yeh, 2005). The larger cash flow right leverage causes higher expropriation. Expropriation is conducted by controlling shareholder to increase the private benefit. According to Kim and Yi (2006), the leverage is an incentive for controlling shareholder to expropriate the company's assets for private benefit and the expense of non-controlling shareholders. It will reduce firm performance. According to Gugler and Yurtoglu (2003), 
the large cash flow right leverage offers incentives and opportunities for controlling shareholder to expropriate non-controlling shareholders.

\section{CONCLUSION}

The results of this study are consistent with the objective of this study. The ultimate ownership negatively influence on firm perfromance. It is reflected on the cash flow right leverage between voting rights and control rights which has negative impact on firm performance. It indicates the leverage has negative meaning for non-controlling shareholders. It implies expropriation by controlling shareholder. These results reflect entrenchment effect of controlling shareholder. This is supported by negative and significant impact of cash flow right leverage on firm performance. Consequently, the larger leverage will cause the lower firm performance. The lower firm performance is negative signal for non-controlling shareholders. It is cost for non-controlling shareholders because the firm could not pay dividend. Dividend is one of revenues for investor. Hedriksen and Breda $(1992 ; 314)$ suggest that the efficient operation of an enterprise affects both the current dividend stream and the use of the invested capital for providing a future dividend stream.

The results indicate management of firm does not operate firm efficiently. It occurs because some management of firm such president director or director is controlling shareholder or family of controlling shareholder. The manager will do for his/his family's best interest not for firm or non-controlling shareholders. It is the real cost for outsides investor or prospective investors. They must consider the cost into risk management. They will attempt to evaluate the efficiency of management before investing or placing a value on the stock of the firm (Hendriksen and Breda, 1992; 314).

The results of this study have some implication. First, the result of this study can be input for Indonesia Financial Service Authority (Otoritas Jasa Keuangan (OJK)) for moniroting in capital market. This institution can identify the public companies which have large or low agency problem indication. It can be known based on cash flow right leverage. The large cash flow right leverage indicates control rights is larger than cash flow rights. It will be incentive for controlling shareholder to missappropiate firm's assets. Therefore, it harms for non-controlling shareholders. OJK should give protection for noncontrolling shareholders or public. Some researcher have found that it will harms for noncontrolling shareholders such as unpaid dividend, earnings management, tunnelings, and etc. OJK should more focus for companies which has large cash flow right leverage than low cash flow right leverage. The large cash flow right leverage will raise entrenchment effect. The low cash flow right leverage or zero cash flow right leverage will raise alignment effect.

The results of this study can inform to regulator or policy makers to make regulation to require public companies to disclose the ultimate ownership. It is very important for public or non-controlling shareholders to consider risk of expropriation on their risk management. They can reduce risk of expropriation. In the Draft of Capital Market Act Republic of Indonesia, it does not require to disclose the ultimate ownership. The regulator also lead the public companies to implement good corporate governance to fulfil conformance. It focuses on ethical value. It is not only complience to the regulations. The results of this study also have implication on practice. Non-controlling shareholders and public must be cautious before they make decisions to buy, hold, or sell. 
The results of this research show the shift of agency problem. In concentrated ownership, the agency problem arises between controlling and non-controlling shareholders commonly. It is not common the agency problem arising between agent and principles. It occurs in contex of dispersed ownership. It is important for next researchers invistigating agency problem in Indonesia.

The limitations of this study are without services industries. This study only uses manufacturing companies as sample. It will impact on level of generalization. Next researchers can combine manufacture and non-manufacture companies in one study to wide generalization. Next researchers can improve this research by including implementation good corporate governance. Because, it will be good or bad for noncontrolling shareholders.

\section{REFERENCES}

Baek, J. S., Kang, J. K., and Park, K. S. (2004) Corporate Governance and Firm Value: Evidence from the Korean Financial Crisis. Journal of Financial Economics, 71: 265-313.

Barontini, R. and Caprio, L. (2004) The Effect of Ownership Structure and Family Control on Firm Value: Evidence from Continental Europe. Working Paper, 49 pages.

Bozec, Y. and Laurin, C. (2008) Large Shareholder Entrenchment and Performance: Empirical Evidence from Canana. Journal of Business Finance \& Accounting, 35: 25-49.

Cadbury Committee. (1992) The Financial Aspects of Corporate Governance. London.

Claessens, S. and Fan, J. P. H. (2002) Corporate Governance in Asia: A Survey. International Review of Finance, 3: 71-103.

Claessens, S., Djankov, S., Fan, J. P. H., and Lang, L. H. P. (1999) Expropriation of Minority Shareholders: Evidence from East Asia. Working Paper. World Bank.

Claessens, S., Djankov, S., and Lang, L. H. P. (2000) The Separation of Ownership and Control in East Asia Corporations. Journal of Financial Economics, 58: 81-112.

Claessens, S., Djankov, S., Fan, J. P. H., and Lang, L. H. P. (2002) Disentangling the Incentive and Entrenchment Effects of Large Shareholders. The Journal of Finance, LVII: 2741-2771.

Dechow, P. M. (1994) Accounting Earnings and Cash Flows as Measure of Firm Performance The Role of Accounting Accruals. Journal of Accounting and Economics, 18: 3-42.

Dechow, P., Kothari, S., and Watts, R. (1998) The relation between earnings and cash flows. Journal of Accounting and Economics, 25, 133-168.

Demsetz, H. and Villalonga, B. (2001) Ownership Structure and Corporate Performance. Journal of Corporate Finance, 7: 209-233.

DetikNews. (2008). Direksi dan Komisaris Bank Century Dicekal. Sabtu, 22 November 2008.

Du, J., and Dai, Y. (2005) Ultimate Corporate Ownership Structures and Capital Structures: Evidence from East Asian Economics. Corporate Governance, 13: 6071. 
Fan, J. P. H. and Wong, T. J. (2002) Corporate Ownership Structure and the Informativeness of Accounting Earnings in East Asia. Journal of Accounting and Economics, 33: 133-152.

Febrianto, R. (2005) The Effect of Ownership Concentration on the Earnings Quality: Evidence from Indonesian Companies. Jurnal Riset Akuntansi Indonesia, 8: 105120.

Gugler, K. and Yurtoglu, B. (2003) Corporate Governance and Dividend Pay Out Policy in Germany. European Economic Review, 47: 731-758.

Hendriksen, E.S. and Breda, M.F.V. (1992). Accounting Theory. Homewood, III: RD. Irwin

Joh, S. W. (2003) Corporate Governance and Firm Profitability: Evidence from Korea before the Economic Crisis. Journal of Financial Economics, 68: 287-322.

Kim, N. B. and Yi, C. H. (2006) Ownership Structure, Business Group Affiliation, Listing Status, and Earnings Management: Evidence from Korea. Contemporary Accounting Research, 23: 427-464.

La Porta, R., Lopez-De-Silanes, F., and Shleifer, A. (1999) Corporate Ownership Around the World. The Journal of Finance, LIV: 471-516.

Lemmon, M. L. and Lins, K. V. (2003) Ownership Structure, Corporate Governance, and Firm Value: Evidence from the East Asian Financial Crisis. The Journal of Finance, LVIII: $1445-1468$.

Lins, K. V. (2003) Equity Ownership and Firm Value in Emerging Markets. Journal of Financial and Quantitative Analysis, 38: 159-184.

Mahkamah Agung. (2010) Putusan MAHKAMAH AGUNG Nomor 615 K/PID.SUS/2010. http://putusan.mahkamahagung.go.id/putusan/2b5d233b519f5fb49ee7f808aeb1bf5a.

Mitton, T. (2002) A Cross-firm Analysis of the Impact of Corporate Governance on the East Asian Financial Crisis. Journal of Financial Economics, 64: 215-241.

Morck, R., Shleifer, A., and Vishny, R. W. (1998) Management Ownership and Market Valuation: An Empirical Analysis. Journal of Financial Economics, 20: 293-315.

Sanjaya, I. P. S. (2011) Agency Problem in Indonesia: the Case of Firms in Manufacturing Industry in Indonesia Stock Exchange. Journal of International Business and Economics, 11: 94-103.

Shleifer, A. and Vishny, R. W. (1997) A Survey of Corporate Governance. The Journal of Finance, LII: 737-783.

Siregar, B. (2008) Ekspropriasi Pemegang Saham Minoritas dan Struktur Kepemilikan Ultimat. Jurnal Riset Akuntansi Indonesia, 11: 237-263.

Villalonga, B. and Amit, R. (2006) How Do Family Ownership, Control and Management Affect Firm Value? Journal of Financial Economics, 80: 385-417.

VIVAnews-Bisnis. (2009) Robert Tantular, Sang Pengendali Century. Rabu, 11 Februari 2009.

Yang, Y. H., Lin, Y. H., and Yen, G. F. (2001) A Study on Efficiency Monitoring and Interest Assimilation in Corporate Governance: Listed Companies in Taiwan. Emerging Market Finance \& Trade, 48: 169-183.

Yeh, Y. H. (2005) Do Controlling Shareholders Enhance Corporate Value? Corporate Governance, 13: 313-325. 